\title{
PENGARUH KARAKTERISTIK KOMITE AUDIT, PREDIKSI KEBANGKRUTAN DAN KEPEMILIKAN PUBLIK TERHADAP AUDIT REPORT LAG
}

\author{
Inneke Kusuma Ratnasari
}

A. Yanti Ardiati

\author{
Program Studi Akuntansi, Fakultas Ekonomi, Universitas Atma Jaya Yogyakarta \\ Jalan Babarsari 43 - 44, Yogyakarta
}

Abstrak

Penyampaian laporan keuangan tahunan di Indonesia diatur secara khusus oleh Otoritas Jasa Keuangan, atau sebelumnya oleh Badan Pengawas Pasar Modal dan Lembaga Keuangan. Seluruh perusahaan yang sahamnya diperdagangkan di Bursa Efek Indonesia wajib menyampaikan laporan keuangan tahunan secara berkala. Laporan keuangan tahunan wajib disampaikan paling lambat pada akhir bulan ketiga.

Penelitian ini dilakukan dengan tujuan untuk menguji pengaruh karakteristik komite audit, prediksi kebangkrutan dan kepemilikan publik berpengaruh terhadap audit report lag. Penelitian dilakukan pada perusahaan manufaktur yang terdaftar di Bursa Efek Indonesia tahun $2010-2014$.

Hasil penelitian menunjukkan bahwa karakteristik komite audit berpengaruh terhadap audit report lag, prediksi kebangkrutan berpengaruh terhadap audit report lag dan kepemilikan publik tidak berpengaruh terhadap audit report lag.

Kata kunci : Audit report lag, Komite Audit, Prediksi Kebangkrutan, Kepemilikan Publik

\section{PENDAHULUAN}

A. Latar Belakang

Laporan keuangan mempunyai peranan penting dalam penilaian kinerja perusahaan serta bermanfaat dalam pengambilan keputusan (Lianto dan Kusuma, 2010). Laporan keuangan harus disampaikan tepat waktu atau sesegera mungkin untuk menghindari hilangnya relevansi informasi yang terdapat didalamnya, sehingga keputusan-keputusan ekonomi dapat segera diambil (Kadir, 2011). Sebaliknya, apabila informasi tersebut tidak disampaikan dengan tepat waktu akan menyebabkan informasi tersebut kehilangan nilai dan mempengaruhi kualitas keputusan (Midansih dan Wibowo, 2011).

Penyampaian laporan keuangan tahunan di Indonesia diatur secara khusus oleh Otoritas Jasa Keuangan, atau sebelumnya oleh Badan Pengawas Pasar Modal dan Lembaga Keuangan. Seluruh perusahaan yang sahamnya diperdagangkan di Bursa Efek Indonesia wajib menyampaikan laporan keuangan tahunan secara berkala. Jangka waktu pengumuman laporan keuangan tahunan diatur dalam Keputusan Ketua Badan Pengawas Pasar Modal dan Lembaga Keuangan Nomor: KEP-346/BL/2011 tentang Penyampaian Laporan Keuangan Berkala Emiten atau Perusahaan Publik. Dinyatakan pada nomor $2 \mathrm{C}$ bahwa laporan keuangan tahunan wajib disampaikan paling lambat pada akhir bulan ketiga (Brian dan Martani, 2014).

Penelitian ini dilatar belakangi oleh fenomena masih banyaknya perusahaan publik di Indonesia yang menyampaikan laporan keuangan lebih dari tanggal 31 Maret. Pada tahun 
2013 terdapat 52 perusahaan terlambat menyampaikan laporan keuangan yang berakhir per 31 Desember 2012. Pada tahun 2014 terdapat 49 perusahaan terlambat menyampaikan laporan keuangan auditan per 31 Desember 2013 dan pada tahun 2015 ada 52 perusahaan terlambat menyampaikan laporan keuangan auditan per 31 Desember 2014 (www.idx.co.id).

Banyak faktor yang mempengaruhi cepat atau lambatnya perusahaan menyampaikan laporan keuangan. Faktor yang mempengaruhi ketepatan waktu penyampaian laporan antara lain karakteristik komite audit, prediksi kebangkrutan dan kepemilikan publik. Komite audit adalah komite yang dibentuk oleh dewan komisaris dalam rangka membantu melaksanakan tugas dan fungsinya. Komite audit bertugas memberikan pendapat kepada dewan komisaris terhadap laporan atau hal-hal yang disampaikan oleh direksi kepada dewan komisaris, mengidentifikasi hal-hal yang memerlukan perhatian komisaris, dan melaksanakan tugas dewan komisaris antara lain melakukan penelaahan atas informasi keuangan yang akan dikeluarkan perusahaan seperti laporan keuangan, proyeksi dan informasi keuangan lainnya (Keputusan Ketua Bapepam Nomor Kep-29/PM/2004). Tujuan dibentuknya komite audit yaitu dalam rangka pengelolaan perusahaan yang baik. Terlaksananya pengelolaan perusahaan yang baik maka integritas pelaporan keuangan akan meningkat. Integritas pelaporan ini dapat dilihat dari ketepatan waktu pelaporan keuangan yang dilakukan oleh perusahaan (Purwanti, 2006).

Perusahaan yang diprediksi bangkrut cenderung akan terjadi penundaan pelaporan keuangan. Hal ini dikarenakan auditor memerlukan waktu yang lebih lama dalam proses audit. Auditor memerlukan data tambahan yang diperlukan untuk dapat menghasilkan opini yang sesuai dengan kondisi perusahaan tersebut (Setyahadi, 2012).

Kepemilikan perusahaan oleh pihak luar mempunyai kekuatan yang besar dalam mempengaruhi perusahaan melalui media massa berupa kritikan atau komentar yang semuanya dianggap suara publik atau masyarakat. Perusahaan dengan proporsi kepemilikan publik yang besar cenderung tepat waktu dalam pelaporan keuangannya (Hilmi dan Ali, 2008). Berdasarkan uraian di atas maka penelitian ini akan meneliti mengenai Pengaruh Karakteristik Komite Audit, Prediksi Kebangkrutan dan Kepemilikan Publik Terhadap Audit Report Lag. Penelitian akan dilakukan pada perusahaan manufaktur yang terdaftar di Bursa Efek Indonesia tahun 2010 - 2014.

\section{B. Rumusan Masalah}

Audit report lag adalah lamanya waktu penyelesaian audit yang diukur dari tanggal penutupan tahun buku atau akhir tahun fiskal sampai diterbitkannya laporan keuangan auditan (Soetedjo, 2006 dalam Parwati dan Suhardjo, 2009). Informasi yang disediakan tepat waktu menyebabkan informasi tersebut relavan sehingga digunakan dalam pengambilan keputusan. Berdasarkan uraian di atas, rumusan masalah dalam penelitian ini adalah:

1. Apakah karakteristik komite audit berpengaruh terhadap audit report lag?

2. Apakah prediksi kebangkrutan berpengaruh terhadap audit report lag?

3. Apakah kepemilikan publik berpengaruh terhadap audit report lag?

\section{Tujuan Penelitian}

1. Untuk mengetahui pengaruh karakteristik komite audit terhadap audit report lag.

2. Untuk mengetahui pengaruh prediksi kebangkrutan terhadap audit report lag.

3. Untuk mengetahui pengaruh kepemilikan publik terhadap audit report lag. 


\section{TINJAUAN PUSTAKA}

\section{A. Karakteristik Komite Audit}

Kemampuan komite audit identik dengan karakteristik yang harus dimiliki oleh komite audit. Oleh karena itu, perusahaan memperhatikan karakteristik yang dimiliki oleh setiap anggota komite auditnya (FCGI, 2002 dalam Maulina dan Sawarjuwono, 2014). Independensi dan kompetensi merupakan atribut penting bagi komite audit. Independensi menekankan pada komite audit yang harus bersikap netral dalam menjalankan perannya dan terutama fokus dalam menemukan solusi dari setiap perbedaan pendapat antara auditor eksternal dan manajemen. Komite audit yang memiliki kemampuan, keahlian serta pengalaman di bidang keuangan dapat membantu dan mendukung auditor eksternal ketika berdiskusi dan berselisih pendapat mengenai kebijakan akuntansi dan manajemen (Lawrence dan Parker, 2002 dalam Maulina dan Sawarjuwono, 2014). Faktor yang dirasakan berkaitan dengan karakteristik komite audit khususnya komunikasi dengan internal audit termasuk dengan mengadakan pertemuan rutin (Bromilow dan Berlin, 2005 dalam Maulina dan Sawarjuwono, 2014).

Kompetensi komite audit menjadi hal yang sangat penting bagi suatu komite audit untuk dapat menjalankan tugasnya dan fungsinya dengan baik. Berdasarkan peraturan Bapepam dan LK Nomor IX.I.5 Lampiran Keputusan Ketua Badan Pengawas Pasar Modal Nomor: Kep-29/PM/2004 tentang Pembentukan dan Pedoman Pelaksanaan Kerja Komite Audit ditentukan bahwa komite audit harus diketahui oleh komisaris independen, dan sekurang-kurangnya salah satu anggotanya memiliki kompetensi dalam bidang akuntansi atau keuangan. Hal ini dibuat dengan pertimbangan bahwa tugas komite audit sangat erat berhubungan dengan masalah akuntansi dalam proses pelaporan keuangan keuangan perusahaan. Komite audit yang diketuai oleh seseorang yang memiliki kompetensi dalam bidang akuntansi, akan meningkatkan kinerja dari komite audit. Hal tersebut dikarenakan tanpa pengetahuan yang memadai dalam bidang akuntansi, maka diduga peran yang dijalankannya sebagai ketua komite audit akan tidak efektif (Sitorus, 2012).

Sartika (2014) menyatakan bahwa semakin baik komite audit menjalankan perannya maka akan semakin singkat waktu penyampaian laporan keuangan, sebab jika komite audit berperan dengan baik maka temuan audit dalam laporan keuangan menjadi semakin sedikit sehingga mempersingkat pelaksanaan audit. Penyelesaian audit yang singkat akan menyebabkan semakin cepat penyampaian laporan keuangan ke Otoritas Jasa Keuangan.

\section{B. Prediksi Kebangkrutan}

Auditor memerlukan waktu yang lebih lama untuk menyelesaikan audit laporan keuangan apabila perusahaan diprediksi bangkrut. Hal ini disebabkan ketika perusahaan diprediksi bangkrut, cenderung akan terjadi penundaan pelaporan keuangan, karena auditor memerlukan waktu yang lebih lama dalam proses audit dan juga auditor memerlukan data tambahan yang diperlukan untuk dapat menghasilkan opini yang sesuai dengan kondisi perusahaan tersebut (Setyahadi, 2012). Proses audit yang lebih lama menyebabkan perusahaan lambat menyampaikan laporan keuangan.

Penelitian Schwartz dan Soo (1996) dalam Syafrudin (2004) menunjukkan bahwa perusahaan yang diprediksi bangkrut cenderung tidak tepat waktu dalam menyampaikan laporan keuangannya dibanding perusahaan yang tidak diprediksi bangkrut. Perusahaan yang diprediksi bangkrut juga merupakan berita buruk (bad news) sehingga perusahaan dengan kondisi seperti ini cenderung tidak tepat waktu dalam pelaporan keuangannya. 


\section{Kepemilikan Publik}

Kepemilikan publik adalah kepemilikan masyarakat umum (bukan institusi yang signifikan) terhadap saham perusahaan publik. Kepemilikan perusahaan oleh pihak luar mempunyai kekuatan besar dalam perusahaan. Kepemilikan perusahaan oleh pihak luar dapat mempengaruhi perusahaan melalui media masa baik berupa kritikan maupun komentar yang semuanya dianggap sebagai suara publik atau masyarakat (Hilmi dan Ali, 2008).

Para pemilik investasi akan mengindikasikan adanya bad news jika perusahaan terlambat mempublikasi laporan keuangan. Hal tersebut akan berpengaruh pada keputusan investasi yang dilakukan investor di masa yang akan datang. Dapat disimpulkan bahwa perusahaan dengan proporsi kepemilikan publik yang besar cenderung segera mempublikasikan laporan keuangan (Haryani dan Wiratmaja, 2014).

Penelitian yang dilakukan oleh Hilmi dan Ali (2008) menunjukkan bahwa perusahaan dengan proporsi kepemilikan publik yang kecil cenderung untuk tepat waktu dalam pelaporan keuangannya. Perusahaan dengan proporsi kepemilikan publik yang besar cenderung untuk tidak tepat waktu dalam pelaporan keuangannya. Hasil penelitian Sulistyo (2010) menunjukkan bahwa kepemilikan publik berpengaruh terhadap ketepatan waktu penyampaian laporan keuangan. Adanya konsentrasi kepemilikan publik maka pihak manajemen akan lebih mendapat tekanan dari pihak luar perusahaan atau shareholder untuk lebih tepat waktu dalam penyampaian laporan keuangan tahunan perusahaan, karena pemegang saham dari pihak luar ingin dengan segera mengetahui informasi perkembangan dan kondisi perusahaan.

D. Hipotesis

H1: Efektivitas komite audit berpengaruh terhadap audit report lag.

H2: Prediksi kebangkrutan berpengaruh terhadap audit report lag.

H3: Kepemilikan publik berpengaruh terhadap audit report lag.

\section{METODE PENELITIAN}

\section{Populasi dan Sampel}

Populasi dalam penelitian ini adalah perusahaan-perusahaan manufaktur yang terdaftar di Bursa Efek Indonesia tahun 2010 - 2014. Kriteria sampel pada penelitian ini adalah:

a. Perusahaan manufaktur yang terdaftar di Bursa Efek Indonesia tahun 2010 - 2014.

b. Akhir tahun buku perusahaan adalah 31 Desember.

c. Tersedia data tanggal penyampaian laporan keuangan ke Otoritas Jasa Keuangan.

d. Laporan keuangan tahunan perusahaan menyediakan data latar belakang pendidikan komite audit, independensi komite audit, piagam komite audit, jumlah komite audit dan jumlah rapat komite audit.

e. Laporan keuangan disajikan dalam satuan rupiah.

Berdasarkan kriteria sampel penelitian, berikut ini proses pemilihan sampel yang telah dilakukan: 
Tabel 1

Sampel Penelitian

\begin{tabular}{|l|c|}
\hline \multicolumn{1}{|c|}{ Keterangan } & Jumlah \\
\hline $\begin{array}{l}\text { Perusahaan manufaktur yang terdaftar di Bursa Efek Indonesia } \\
\text { secara berturut-turut tahun 2010 - 2014 }\end{array}$ & 127 \\
\hline Akhir tahun buku perusahaan tidak 31 Desember & $(0)$ \\
\hline $\begin{array}{l}\text { Tidak tersedia data tanggal penyampaian laporan keuangan ke } \\
\text { Otoritas Jasa Keuangan }\end{array}$ & $(0)$ \\
\hline $\begin{array}{l}\text { Laporan keuangan tahunan perusahaan tidak menyediakan data } \\
\text { latar belakang pendidikan komite audit, independensi komite } \\
\text { audit, piagam komite audit, jumlah komite audit dan jumlah rapat } \\
\text { komite audit }\end{array}$ & $(77)$ \\
\hline Laporan keuangan tidak disajikan dalam satuan rupiah & $(11)$ \\
\hline Sampel Penelitian & $\mathbf{3 9}$ \\
\hline Total Data Observasi (39 perusahaan x 5 tahun) & $\mathbf{1 9 5}$ \\
\hline
\end{tabular}

\section{Data dan Cara Pengumpulan Data}

Data yang digunakan dalam penelitian ini adalah data sekunder yaitu laporan keuangan. Laporan tahunan perusahaan diperoleh dari website perusahaan dan website Bursa Efek Indonesia.

\section{Definisi Operasional Variabel dan Pengukuran}

Variabel dalam penelitian ini terdiri dari dua jenis yaitu variabel dependen (Y) dan variabel independen $(\mathrm{X})$.

\section{a. Variabel dependen}

Variabel dependen dalam penelitian ini adalah audit report lag. Audit report lag adalah lamanya waktu penyelesaian audit yang diukur dari tanggal penutupan tahun buku atau akhir tahun fiskal sampai diterbitkannya laporan keuangan auditan (Soetedjo, 2006 dalam Parwati dan Suhardjo, 2009).

\section{b. Variabel independen}

Variabel independen dalam penelitian ini adalah efektivitas komite audit, prediksi kebangkrutan dan kepemilikan publik.

1) Efektivitas Komite Audit

Efektivitas komite audit berarti kemampuan komite audit dalam memenuhi tugas dan tanggung jawab pengawasannya (DeZoort et al., 2002 dalam Maulina dan Sawarjuwono, 2014). Skor indeks efektivitas komite audit yang digunakan penelitian ini adalah sebagai berikut:

a) Komposisi Komite Audit

Komposisi komite audit terdiri dari independensi komite audit dan keahlian komite audit.

1. Independensi komite audit

Jika semua anggota komite audit merupakan pihak luar perusahaan diberi nilai 1. Jika salah satu atau lebih komite audit merupakan pihak dalam perusahaan maka diberi nilai 0 .

2. Keahlian komite audit

Jika paling sedikit 1 orang anggota komite audit berlatar belakang pendidikan dan berpengalaman dalam bidang akuntansi atau keuangan diberi nilai 1 , sebaliknya 0 . 
b) Kewenangan Komite Audit

Kewenangan komite audit diukur dari dari ada tidaknya piagam komite audit. Jika terdapat piagam diberi nilai 1 dan jika tidak ada piagam diberi nilai 0 .

c) Sumber Daya Komite Audit

Sumber daya komite audit diukur dari jumlah anggota komite audit. Jika jumlah anggota komite audit kurang dari 3 orang diberi nilai 0 , dan jika jumlah anggota komite audit 3 orang atau lebih diberi nilai 1.

d) Kerajinan Komite Audit

Kerajinan komite audit diukur dari jumlah rapat komite audit. Jika anggota dewan komite audit melakukan rapat paling sedikit 4 kali dalam satu tahun diberi nilai 1 , sebaliknya 0 .

Total skor tertinggi adalah 5. Indeks efektivitas komite audit diukur dengan rumus sebagai berikut:

Indeks efektivitas komite audit $=\frac{\begin{array}{l}\text { Total Skor efektivitas komite audit } \\ \text { perusahaan }\end{array}}{5}$

2) Prediksi Kebangkrutan

Prediksi kebangkrutan menunjukkan perusahaan yang bermasalah dalam keuangan yaitu perusahaan tidak mampu memenuhi kewajiban atau mengarah pada kebangkrutan (Eko, 2005 dalam Setyaningsih, 2008). Model prediksi kebangkrutan menggunakan model Zmijewski. Zmijewski (1984) menggunakan analisis rasio yang mengukur kondisi keuangan perusahaan dengan menggunakan rasio leverage dan likuiditas untuk model prediksinya. Model yang dikembangkannya adalah sebagai berikut:

$\mathrm{X}=-4,3-4,5 \mathrm{X} 1+5,7 \mathrm{X} 2-0,004 \mathrm{X} 3$

Keterangan:

$\mathrm{X} 1=\mathrm{ROA}$ (return on asset)

$\mathrm{X} 2=$ Leverage (debt ratio)

$\mathrm{X} 3=$ Likuiditas (current ratio)

Dari hasil perhitungan model Zmijewski diperoleh nilai X-Score yang dibagi dalam dua kategori, yaitu jika X-score bernilai negatif, maka perusahaan tersebut dalam kondisi yang sehat, sebaliknya jika X-score bernilai positif maka perusahaan tersebut dalam kondisi yang tidak sehat atau cenderung mengarah ke kebangkrutan.

3) Kepemilikan Publik

Kepemilikan publik adalah kepemilikan masyarakat umum (bukan institusi yang signifikan) terhadap saham perusahaan publik (Hilmi dan Ali, 2008). Rumus kepemilikan publik adalah sebagai berikut:

$$
\text { Kepemilikan publik }=\frac{\text { Jumlah saham yang dimiliki publik }}{\text { Jumlah saham perusahaan }}
$$




\section{Model Regresi}

Model regresi linier berganda adalah sebagai berikut:

$\mathrm{ARL}=\alpha_{0}+\alpha_{1} \mathrm{KA}+\alpha_{2}$ PREDIKSI $+\alpha_{3}$ PUBLIK $+e$

Keterangan:

$\begin{array}{ll}\text { ARL } & =\text { Audit Report Lag } \\ \alpha_{0} & =\text { intersep } \\ \alpha_{1-3} & =\text { koefisien regresi } \\ \text { KA } & =\text { Efektivitas komite audit } \\ \text { PREDIKSI } & =\text { Prediksi Kebangkrutan } \\ \text { PUBLIK } & =\text { Kepemilikan publik } \\ \mathrm{e} & =\text { Error }\end{array}$

\section{HASIL PENELITIAN}

Pengujian hipotesis dalam penelitian ini menggunakan analisis regresi berganda. Hasil analisis regresi berganda dalam penelitian ini adalah sebagai berikut:

Tabel 2

Hasil Pengujian Hipotesis

\begin{tabular}{|c|c|c|c|c|c|}
\hline \multirow[t]{2}{*}{ Variabel } & \multicolumn{2}{|c|}{$\begin{array}{l}\text { Unstandardized } \\
\text { Coefficients }\end{array}$} & \multirow[b]{2}{*}{$\mathrm{t}$} & \multirow[b]{2}{*}{ Sig } & \multirow{2}{*}{ Simpulan } \\
\hline & $\mathrm{B}$ & Std. Error & & & \\
\hline (Constant) & 102,361 & 2,644 & 38,710 & 0,000 & \\
\hline Efektivitas komite audit & $-17,432$ & 2,918 & $-5,974$ & 0,000 & H1 diterima \\
\hline Prediksi Kebangkrutan & 0,589 & 0,243 & 2,423 & 0,017 & H2 diterima \\
\hline Kepemilikan publik & 2,696 & 2,543 & 1,060 & 0,291 & H3 tidak diterima \\
\hline F hitung & 13,653 & & & & 13,653 \\
\hline Sig. & 0,000 & & & & 0,000 \\
\hline Adj $R$ Square & 0,192 & & & & 0,192 \\
\hline
\end{tabular}

Berdasarkan hasil analisis regresi maka dapat dibuat suatu model persamaan regresi linier berganda sebagai berikut:

$\mathrm{ARL}=102,261-17,432 \mathrm{KA}+$ 0,589 PREDIKSI + 2,696 PUBLIK

Keterangan:

ARL $\quad=$ Audit Report Lag

KA $\quad=$ Efektivitas Komite Audit

PREDIKSI $=$ Prediksi kebangkrutan

PUBLIK $=$ Kepemilikan Publik

Berikut ini adalah hasil pengujian hipotesis dengan regresi berganda.

Uji F digunakan untuk menguji pengaruh karakteristik komite audit, prediksi kebangkrutan dan kepemilikan publik secara simultan terhadap audit report lag. Nilai probabilitas uji $\mathrm{F}$ sebesar 0,000. Nilai probabilitas uji $\mathrm{F}<0,05$ menunjukkan bahwa karakteristik komite audit, prediksi kebangkrutan dan kepemilikan publik secara simultan berpengaruh terhadap audit report lag.

Uji koefisien determinasi digunakan untuk mengukur sejauh mana kemampuan variabel independen menjelaskan perubahan variabel dependen. Nilai adjusted $\mathrm{R}$ Square yang diperoleh dari hasil analisis regresi berganda adalah 0,192. Hal tersebut menunjukkan bahwa karakteristik komite audit, prediksi kebangkrutan dan kepemilikan 
publik mampu menjelaskan perubahan audit report lag sebesar 19,2\% sedangkan sisanya $80,8 \%$ dijelaskan oleh variabel lain.

Berikut ini merupakan penjelasan pengujian hipotesis yang telah dilakukan:

1. Pengaruh Karakteristik Komite Audit Terhadap Audit Report Lag

Tabel 2 menunjukkan nilai koefisien regresi variabel karakteristik komite audit sebesar $-17,432$ dan nilai probabilitas sebesar 0,000, sehingga dapat disimpullkan bahwa karakteristik komite audit berpengaruh terhadap audit report lag. Nilai koefisien regresi negatif menunjukkan bahwa ketika anggota komite audit berasal dari luar perusahaan, anggota komite audit berlatar belakang pendidikan dan berpengalaman dalam bidang akuntansi atau keuangan, memiliki piagam komite audit, jumlah anggota komite audit 3 orang dan melakukan rapat lebih dari 4 kali dalam satu tahun maka audit report lag lebih pendek.

Tugas komite audit sangat erat berhubungan dengan masalah akuntansi dalam proses pelaporan keuangan perusahaan. Oleh sebab itu, komite audit yang diketuai oleh seseorang yang memiliki kompetensi dalam bidang akuntansi, akan meningkatkan kinerja dari komite audit. Karena tanpa pengetahuan yang memadai dalam bidang akuntansi, maka diduga peran yang dijalankannya sebagai ketua komite audit akan tidak efektif (Sitorus, 2012).

Sartika (2014) menyatakan bahwa semakin baik komite audit menjalankan perannya maka akan semakin singkat waktu penyampaian laporan keuangan, sebab jika komite audit berperan dengan baik maka temuan dalam laporan keuangan menjadi semakin sedikit sehingga mempersingkat pelaksanaan audit. Penyelesaian aduit yang singkat akan menyebabkan semakin cepat penyampaian laporan keuangan ke Otoritas Jasa Keuangan.

Hasil penelitian ini sesuai dengan hasil penelitian Ika dan Ghazali (2011) yang menunjukkan bahwa karakteristik komite audit akan mengurangi waktu penyampaian laporan keuangan.

2. Pengaruh Prediksi Kebangkrutan Terhadap Audit Report Lag

Tabel 2 menunjukkan nilai koefisien regresi variabel prediksi kebangkrutan sebesar 0,589 dan nilai probabilitas sebesar 0,017 sehingga dapat disimpullkan bahwa prediksi kebangkrutan berpengaruh terhadap audit report lag. Nilai koefisien regresi positif menunjukkan bahwa saat perusahaan tidak sehat maka waktu penyampaian laporan keuangan lebih lama.

Auditor memerlukan waktu yang lebih lama untuk menyelesaikan audit laporan keuangan apabila perusahaan diprediksi bangkrut. Hal ini disebabkan ketika perusahaan diprediksi bangkrut, cenderung akan terjadi penundaan pelaporan keuangan, karena auditor memerlukan waktu yang lebih lama dalam proses audit dan juga auditor memerlukan data tambahan yang diperlukan untuk dapat menghasilkan opini yang sesuai dengan kondisi perusahaan tersebut (Setyahadi, 2012). Proses audit yang lebih lama menyebabkan perusahaan lambat menyampaikan laporan keuangan.

Penelitian Schwartz dan Soo (1996) dalam Syafrudin (2004) menunjukkan bahwa perusahaan yang diprediksi bangkrut cenderung tidak tepat waktu dalam menyampaikan laporan keuangannya dibanding perusahaan yang tidak diprediksi bangkrut. Perusahaan yang diprediksi bangkrut merupakan berita buruk (bad news) sehingga perusahaan dengan kondisi seperti ini cenderung tidak tepat waktu dalam pelaporan keuangannya. Hasil penelitian ini sesuai dengan hasil 
penelitian Ika dan Ghazali (2012) serta Aini dkk (2014) yang menunjukkan bahwa perusahaan yang diprediksi bangkrut cenderung melaporkan laporan tahunan mereka lebih lama.

\section{Pengaruh Kepemilikan Publik Terhadap Audit Report Lag}

Tabel 2 menunjukkan nilai koefisien regresi variabel kepemilikan publik sebesar 2,696 dan nilai probabilitas sebesar 0,291 sehingga kepemilikan publik tidak berpengaruh terhadap audit report lag.

Hal ini dikarenakan kepemilikan saham publik kurang dari 50\% yaitu sekitar 27,18\%. Kecilnya presentase kepemilikan pihak luar ini akan mempengaruhi hak suara yang dimilikinya. Kondisi ini mengakibatkan hak suara (kewenangan) terhadap perusahaan kecil juga, sehingga peranannya tidak terlalu besar dalam menentukan kebijakan perusahaan terutama yang menyangkut segi pelaporan keuangan (Awaludin dan Sawitri, 2012). PSAK 4 menyatakan bahwa kontrol pemegang saham dianggap efektif apabila lebih dari 50\% hak suara.

Hasil penelitian ini konsisten dengan hasil penelitian Saleh (2004), Suharli dan Rachpriliani (2006) serta Awalludin dan Sawitri (2012) yang menunjukkan bahwa kepemilikan publik tidak berpengaruh terhadap ketepatan waktu penyampaian laporan keuangan.

\section{KESIMPULAN}

1. Karakteristik komite audit berpengaruh terhadap audit report lag. Ketika anggota komite audit berasal dari luar perusahaan, anggota komite audit berlatar belakang pendidikan dan berpengalaman dalam bidang akuntansi atau keuangan, memiliki piagam komite audit, jumlah anggota komite audit 3 orang dan melakukan rapat lebih dari 4 kali dalam satu tahun maka audit report lag lebih pendek

2. Prediksi kebangkrutan berpengaruh terhadap audit report lag. Perusahaan diprediksi bangkrut maka waktu penyampaian laporan keuangan lebih lama.

3. Kepemilikan publik tidak berpengaruh terhadap audit report lag.

\section{G. Implikasi}

Hasil penelitian menunjukkan bahwa karakteristik komite audit dan prediksi kebangkrutan berpengaruh terhadapa audit report lag. Berdasarkan hal tersebut maka pihak perusahaan diharapkan meningkatkan kinerja komite audit sebab dengan adanya kinerja komite audit yang baik maka perusahaan cenderung menyampaikan laporan keuangan tepat waktu. Selain itu peningkatan kinerja harus selalu dilakukan guna menghindari terjadinya kebangrutan perusahaan. Perusahaan yang tidak diprediksi bangkrut akan menyampaikan laporan keuangan tepat waktu.

\section{H. Keterbatasan Penelitian}

Penelitian ini memiliki keterbatasan yaitu penelitian ini tidak menggunakan indikator tanggung jawab komite audit dan pengungkapan sukarea komite audit dalam pengukuran variabel karakteristik komite audit. Hal ini dikarenakan tidak ada pengukuran yang jelas mengenai penjelasan secara detail, singkat atau tidak mengungkapkan tanggung jawab komite audit. 


\section{DAFTAR PUSTAKA}

Aini. Nurul, Lili Sugeng Wiyantoro dan Helmi Yazid. 2014. Keterkaitanantara Keefektifan Komite Audit dan Profitabilitas Perusahaan dengan Financial Reporting Lead Time (Studi Empiris pada Perusahaan di Banten yang Listing di Bursa Efek Indonesia pada tahun 2009-2012). Simposium Nasional Akuntansi 17. Mataram

Awaludin, Vita Magdalena dan Peni Sawitri. 2012. Analisis Faktor-Faktor Yang Mempengaruhi Ketepatan Waktu Pelaporan Keuangan Pada Perusahaan Manufaktur Yang Terdaftar Di Bursa Efek Indonesia. Fakultas Ekonomi Universitas Gunadarma

Brian Ivan dan Dwi Martani. 2014. Analisis Pengaruh Penghindaran Pajak dan Kepemilikan Keluarga Terhadap Waktu Pengumuman Laporan Keuangan Tahunan Perusahaan. Simposium Nasional Akuntansi 17. Mataram.

Haryani, Jumratul dan I Dewa Nyoman Wiratmaja. 2014. Pengaruh Ukuran Perusahaan, Komite Audit, Penerapan International Financial Reporting Standards dan Kepemilikan Publik pada Audit Delay. E-Jurnal Akuntansi Universitas Udayana. Volume 6. Nomor 1

Hilmi, Utari dan Syaiful Ali. 2008. Analisis Faktor-Faktor yang Mempengaruhi Ketepatan Waktu Penyampaian Laporan Keuangan (Studi Empiris pada Perusahaan-perusahaan yang Terdaftar di BEJ Periode 2004-2006). Simposium Nasional Akuntansi 11

Ika, Siti Rochmah dan Nazli A. Mohd Ghazali. 2011. Audit Committee Effectiveness and Timeliness of Reporting: Indonesian Evidence. Managerial Auditing Journal. Vol. 27. No. 4

Kadir, Abdul. 2011. Faktor-Faktor yang Berpengaruh Terhadap Ketepatan Waktu Pelaporan Keuangan Studi Empiris Pada Perusahaan Manufaktur Di Bursa Efek Jakarta. Jurnal Manajemen dan Akuntansi. Volume 12. Nomor 1

Keputusan Ketua Bapepam Nomor Kep-29/PM/2004

Lianto, Novice dan Budi Hartono Kusuma. 2010. Faktor-Faktor yang Berpengaruh Terhadap Audit Report Lag. Jurnal Bisnis dan Akuntansi. Volume 12. Nomor 2

Maulina, Febi Citra dan Tjiptohadi Sawarjuwono. 2014. Efektivitas Komite Audit dalam Sudut Pandar Auditor Internal pada PT Semen Indonesia (Persero) Tbk. Simposium Nasional Akuntansi 17. Mataram.

Midansih, Ken dan Wibowo. 2011. Faktor-Faktor yang Mempengaruhi Ketepatan Waktu Pelaporan Keuangan pada Perusahaan Manufaktur yang Terdaftar pada Bursa Efek Indonesia Periode 2005 - 2007. Jurnal Informasi, Perpajakan, Akuntansi dan Keuangan Publik. Volume 6. Nomor 1. Halaman $55-70$.

Parwati, Lina Anggraeny dan Yohanes Suhardjo. 2009. Faktor-Faktor yang Mempengaruhi Audit Report Lag (ARL). Solusi. Volume 8. Nomor 3. Halaman 29 - 42. 
Purwanti, Atiek Sri. 2006. Pengaruh Karakteristik Komite Audit Terhadap Ketepatan Waktu Pelaporam Keuangan pada Perusahaan Publik yang Tercatat di BEJ. Tesis. Universitas Diponegoro. Semarang

Saleh. Rachmat. 2004. Studi Empiris Ketepatan Waktu Pelaporan Keuangan Perusahaan Manufaktur di Bursa Efek Jakarta. Simposium Nasional Akuntansi 7

Sartika, Riyan. 2014. Pengaruh Peran Komite Audit, Reputasi KAP dan Ukuran Perusahaan Terhadap Ketepatan Waktu Penyampaian Laporan Audit (Studi Empiris pada Perusahaan Perbankan dan Perusahaan Asuransi yang Terdaftar di BEI). Artikel Skripsi. Universtas Negeri Padang.

Setyahadi, R. Rulick. 2012. Pengaruh Probabilitas Kebangkrutan pada Audit Delay. Tesis. Universitas Udaya. Denpasar

Setyaningsih, Hesty. 2008. Pengaruh Tingkat Kesulitan Keuangan Perusahaan Terhadap Konservatisme Akuntansi. Jurnal Akuntansi dan Investasi. Volume 9. Nomor 1. Halaman $91-107$

Sitorus, Irma Julian. 2012. Analisis Peran Komite Audit yang Efektif dan Independensi Dewan Komisaris (Studi pada Badan Usaha Milik Negara yang Terdaftar pada Bursa Efek Indonesia). Seminar Nasional Akuntansi dan Bisnis. Bandung

Suharli, Michell dan Awaliawati Rachpriliani. 2006. Studi Empiris Faktor Yang Berpengaruh Terhadap Ketepatanwaktu Pelaporan Keuangan. Jurnal Bisnis dan Akuntansi. Volume 8. Nomor 1. Halaman $34-55$

Sulistyo, Wahyu Adhy Noor. 2010. Analisis Faktor-Faktor Faktor yang Berpengaruh Terhadap Ketepatanwaktu Penyampaian Laporan Keuangan pada Perusahaan yang Listing di Bursa Efek Indonesia Periode 2006 - 2008. Skripsi. Universitas Diponegoro. Semarang

Syafrudin, M. 2004. Pengaruh Ketidaktepatwaktuan Penyampaian Laporan Keuangan pada Earning Response Coefficient: Studi di Bursa Efek Jakarta. Simposium Nasional Akuntansi VII Ikatan Akuntan Indonesia. Hal: 754-776.

$\underline{\text { www.idx.co.id }}$ 